\title{
Do pigments reflect the turnover of plant material in food chain studies? Analysis of plant pigments in the intestine of Saduria (Mesidotea) entomon
}

\author{
Doris Abele-Oeschger ${ }^{1}$, Anna Szaniawska ${ }^{2}$, Hans Theede ${ }^{1}$
}

${ }^{1}$ Universität Bremen, Meereszoologie - Aufenstelle, Bürgermeister-Smidt-Str. 20, W-2850 Bremerhaven, Germany

${ }^{2}$ University of Gdańsk, Institute of Oceanography, ul. Czolgistow 46, Gdynia, Poland

\begin{abstract}
Pigments are frequently used as biomarkers to study the fate of primary producers in the food web. We evaluated the effectiveness of pigment analysis in the giant aquatic isopod Saduria entomon, an important link in the food chain of the Baltic Sea. Specimens were collected on a transect across Puck Bay (Gulf of Gdańsk, Poland) at stations comprising different sedimentary conditions and varying supply of micro- and macroalgal material. In laboratory experiments $S$. entomon was fed different kinds of prey. Different marker combinations were found in the intestinal tissue, resulting from predation on herbivorous and carnivorous species. Analyses of field samples revealed that $S$. entomon, living in the sediment surface, ingests freshly sedimented phytoplankton as well as plant detritus. $\beta$-carotene and the xanthophyll echinenone were found in the carapax and gonads, supporting the view that these substances are assimilated and serve as antioxidant protection of lipids and other macromolecules.
\end{abstract}

\section{INTRODUCTION}

The giant isopod Saduria entomon is a glacial relict, found in various parts of the eastern and northern Baltic (Theede 1974). It can also live in fresh water conditions and appears in several Scandinavian lakes. Its ecology and behaviour have been extensively studied by Leonardsson (1990), Haahtela (1990), Sandberg \& Bonsdorf (1990), and Kivivuori \& Lagerspetz (1990). $S$. entomon is a stenothermic cold water animal occurring in water depths between 10 and $30 \mathrm{~m}$, where it lives buried in the sediment. High tolerance towards low oxygen conditions (Hagerman \& Szaniawska 1988, 1990) enables this species to colonize bottom sediments where extended periods of anoxia are common events. According to Haahtela (1990) and Sandberg \& Bonsdorff (1990) S. entomon is mainly a scavenger feeding on dead benthic animals. Leonardsson (1990) also found cannibalism to be an important mechanism for regulation of population density.

The question we address here is whether turnover of primary production (i.e. macroalgae, phytoplankton) can be traced to the second trophic level, (i.e. an omnivorous or carnivorous second predator in the food chain), by the analysis of plant pigments and their derivatives. Pigments are widely used to study the abundance and composition of different groups of primary producers in the water column (Lehmann 1981, Gieskes \& Kraay 1983, 1984, Wright \& Jeffrey 1987, Bianchi \& Findlay 1990), as well as their contribution to the detrital pool in marine sediments (Züllig 1982, Riaux-Gobin et al. 1987, Abele 1988, Abele-Oeschger 1991). Pigments are also used as markers in food chain studies (Liaaen-Jensen 1990, 1991), and for this purpose stability against animal and microbial digestion is essential. We analysed plant pigments in the intestinal tract of Saduria entomon collected at 5 different stations varying considerably in sediment and supply of algal material. In laboratory experiments, $S$. entomon was fed different kinds of prey, to see how pigments in the intestinal tract reflect predation on different kinds of animals.

The primary objectives of this study were: (1) to recover any intact plant pigment from the intestinal 
tract of Saduria entomon; (2) to find pigment derivatives which may indicate that plant material was digested by $S$. entomon; (3) to measure combinations of pigments and breakdown products resulting from $S$. entomon foraging on other herbivorous and carnivorous species. This is of particular interest with regard to the general question of the stability of pigment markers.

\section{MATERIAL AND METHODS}

Samples of Saduria entomon were collected at 5 different stations in Puck Bay (Gulf of Gdańsk, Poland) for analysis of pigments in the intestinal tract. In June, August and September 1990, samples were taken at 4 stations in the bay with different sediment conditions and varying food supply (Stns 1 to 4 ; Fig. 1).

Water depth ranged from $34 \mathrm{~m}$ (Stn 1) to $6 \mathrm{~m}$ in the shallower regions (Stn 4). The sediment was primarily composed of mud at Stns 1 and 3 (10 m water depth), and sand at Stn 2 in $17 \mathrm{~m}$ depth. At the shallowest (Stn 4 ) in $6 \mathrm{~m}$ depth the sandy sediment was covered with dense macroalgal stocks of the species Pilayella littoralis and Ceramium sp.

A 5th station with muddy sediment in $32 \mathrm{~m}$ water depth was sampled in August and September.

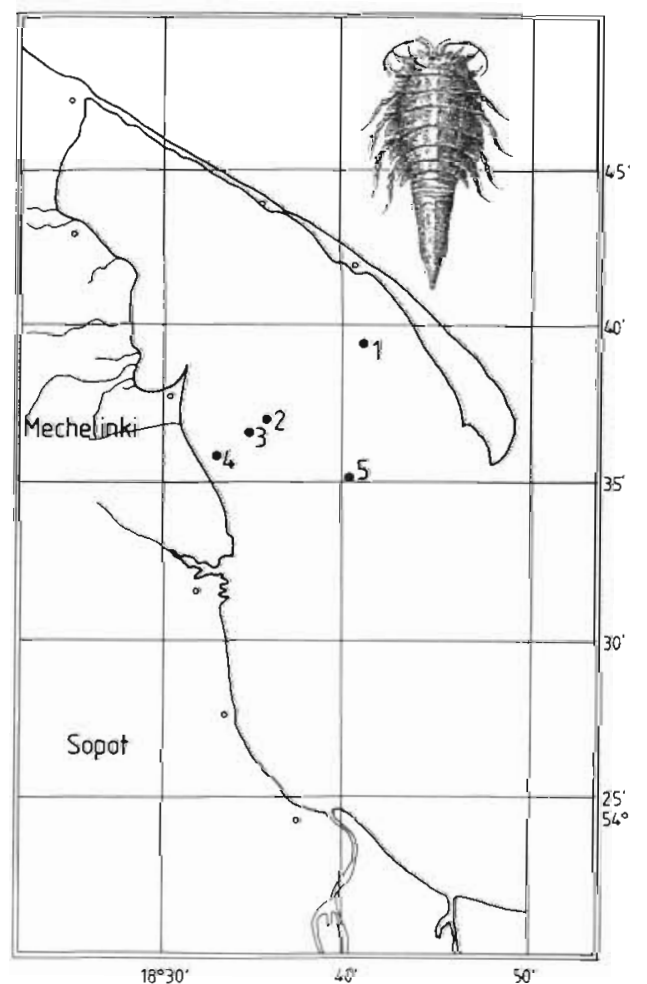

Fig. 1 Puck Bay, Gulf of Gdańsk, Poland, with sampling stations marked
On each sampling date 5 to 8 specimens were taken and kept frozen at $-20^{\circ} \mathrm{C}$ until pigment analysis.

To investigate whether different kinds of prey leave distinct markers or marker combinations in the stomach of Saduria entomon, a feeding experiment was performed at the Institute of Oceanography, University of Gdańsk. Six basins each with 3 to 5 specimens were kept at $5{ }^{\circ} \mathrm{C}$ and $7.5 \%$ salinity. While one group of isopods stayed without food, the other 5 groups were provided with different kinds of prey for 1 wk (Table 1). Prey was chosen to include a herbivorous species (Mytilus edulis), and a carnivorous species (Crangon crangon) as well as a fish (Zoarces viviparus) and $S$. entomon itself. The green macroalgae Enteromorpha spp. was offered as plant material. After $1 \mathrm{wk}$ of exposure to differing food, all specimens were killed and the intestinal tract (including stomach, fore- and hind-gut, and digestive gland) removed and stored deep frozen until analysis in Bremerhaven, Germany. The residual body (including carapax and gonads) was freezedried, homogenized, and subsequently treated as all other samples.

Thawed samples were homogenized in organic solvents (acetone: methanol, $3: 4 \mathrm{v} / \mathrm{v}$ ) and extracted for $3 \mathrm{~h}$ in the dark and at room temperature. Thereafter the samples were centrifuged $(14000 \times g$. $3 \mathrm{~min}$ ) and the extract decanted. The pellets were redissolved in acetone/methanol extraction media and samples were mixed and extracted for another $2 \mathrm{~h}$. The 2 extracts were combined and the organic solvent removed by vacuum evaporation. Pigments were resolved in a defined volume between 500 and $1000 \mu l$ of $100 \%$ methanol and directly injected into high performance liquid chromatography (HPLC) columns. Parallels were taken for measurement of water content, in order to calculate $\mu \mathrm{g}$ pigment $\mathrm{g}^{-1}$ dry wt of tissue.

Pigment separation was performed using 2 different methods. For the in situ samples the method of Juhler \& Cox (1990) was used, which separates the stereoisomers lutein and zeaxanthin. In this case

Table 1 Experimental groups for testing pigment uptake by the marine isopod Saduria entomon resulting from differing prey. $\mathrm{T}=5^{\circ} \mathrm{C}, \mathrm{S}=7.5 \%$

\begin{tabular}{ccl}
\hline Group & $\begin{array}{c}\text { No. of S.entomon } \\
\text { individuals }\end{array}$ & Prey \\
\hline 1 & 4 & Without food \\
2 & 5 & Saduria entomon \\
3 & 5 & Mytilus edulis \\
4 & 5 & Zoarces viviparus \\
5 & 3 & Enteromorphaspp \\
6 & 3 & \\
\hline
\end{tabular}


pigments were extracted in acetone/methanol $(3: 4, v / v)$ and separated on a $250 \mathrm{~mm}$ Spherisorb RP-C18 ODS II column with a THF (tetrahydrofuran) water gradient.

Samples of intestinal tracts from the feeding experiment were separated by a linear methanol/water to methanol/acetone gradient according to the method of Mantoura \& Llewellyn (1983). For a detailed description of the method see Abele-Oeschger (1991). Again a Spherisorb RP-C18 ODS II column was used. The same procedure was applied to sediment samples from the experimental basins. All organic solvents were HPLC-grade and degassed prior to use. Flow rate was $1.5 \mathrm{ml} \mathrm{min}^{-1}$ and the resulting pressure between 200 and 300 bar.

Identification of pigment components was achieved by co-chromatography using standard solutions which were prepared from plant tissue with known pigment composition. A chlorophyll a standard was purchased from Serva (Serva A 16910). For echinenone, a standard was provided by Hoffmann LaRoche, Basel, Switzerland. The presence of echinenone and $\beta$-carotene in carapax samples was confirmed by mass spectrometry (PDMS) at the Department of Theoretical Physics, Oldenburg University, Germany. Chlorophyll $c$ and the xanthophylls fucoxanthin, diadinoxanthin and diatoxanthin were extracted from Fucus vesiculosus thalli. Lutein and neoxanthin were isolated from spinach leaves. For preparation of standards, pigments were separated on Merck TLC aluminium sheets silica gel 60 . The mobile phase was $40 \%$ acetone in hexane. Separated compounds were scraped from plates, redissolved in acetone and absorption spectra were recorded between 400 and $700 \mathrm{~nm}$. The amounts of pigments in the standard solutions were calculated from the maximum absorption in the spectra using the extinction coefficient for solutions $\left(\epsilon^{1 / 1 / n}\right)$. These standard solutions were diluted and reinjected into HPLC to obtain a relation of amount to peak area for each component.

Chlorophylls were measured fluorometrically. The amounts of the derivatives pheophytin $a$, pheophorbide $a$ and also chlorophyllide were calculated on the basis of chlorophyll a fluorescence by multiplying by fluorescence coefficients on a gravimetric basis according to Dawson et al. (1985).

In most samples a fluorescence peak occurred shortly before chlorophyll a. Analysis of a stomach sample by mass spectrometry showed a single peak with a mass of 808 , slightly lighter than the derivative pyropheophytin a (813). Pyropheophytin is a chlorophyll derivative, lacking the carbimethoxi- moiety on ring $\mathrm{V}$ and the central $\mathrm{Mg}^{2+}$. The component we had was slightly more polar than chlorophyll $a$ and fluoresced; we refer to it as a pyropheophytin-like derivative. For quantification the gravimetric factor given by Dawson et al. (1985) for pheophytin a was used.

For statistical analysis the data from the in situ samples were transformed to $\log (x)$, and a $t$-test at $95 \%$ significance level was performed.

\section{RESULTS}

\section{In situ samples}

Most Saduria entomon specimens collected in the Gulf of Gdańsk contained measurable amounts of various plant pigments. Chlorophylls $a$ and $c$ plus 3 different chlorophyll a derivatives were measured in the intestine. Among the very diverse class of carotenoids, $\beta$-carotene, fucoxanthin, and in 1 sample the cyanophyte marker echinenone were found. Concentrations of each pigment ranged between 0.01 and $20 \mu \mathrm{g} \mathrm{mg}^{-1}$ dry wt extracted tissue (Figs. $2 \& 3$ ). In a third $(35 \%)$ of all individuals, however, no pigments were detected

Stn 4 differed considerably from the other 3 stations. Specimens collected at the 3 deeper stations contained very small amounts of pigments. Chlorophylls a and $c$ were below or just around the detection limit. The diatom marker fucoxanthin was also found in a low concentration range. Pheophorbide and the pyropheophytin-like pigment were the major chlorophyll components, but the highest concentrations were below $0.05 \mu \mathrm{g} \mathrm{mg}^{-1}$ dry wt of tissue.

At $\operatorname{Stn} 4$, Saduria entomon lives in sediment overgrown by macroalgae. Here, their intestinal tissue contained chlorophyll $c_{\text {, }}$ and although no intact chlorophyll a was found, pheophorbide $a$, a pigment generated during animal digestion of chlorophyll a (Downs \& Lorenzen 1985, Bianchi et al. 1988, Abele-Oeschger \& Theede 1991), occurred at significantly higher concentrations than at the other 3 stations. The pyropheophytin-like chlorophyll and the xanthophyll fucoxanthin were the only other pigments present and appeared in slightly higher concentrations compared to the 3 deeper stations (Fig. 2).

Intact chlorophyll $a$, which can be seen as direct proof of herbivore feeding, was observed in 1 sample of Saduria entomon collected in mid-August 1990. In specimens collected on that day chlorophyll a values were significantly higher while pheophorbide concentrations were negligible; the pigment dominating these samples was echinenone (Fig. 3)

HPLC analyses of the carapax samples yielded 2 peaks, one of which was clearly identified as the keto-xanthophyll echinenone. Mass-spectrometric analysis of the carapax samples yielded mass peaks at 


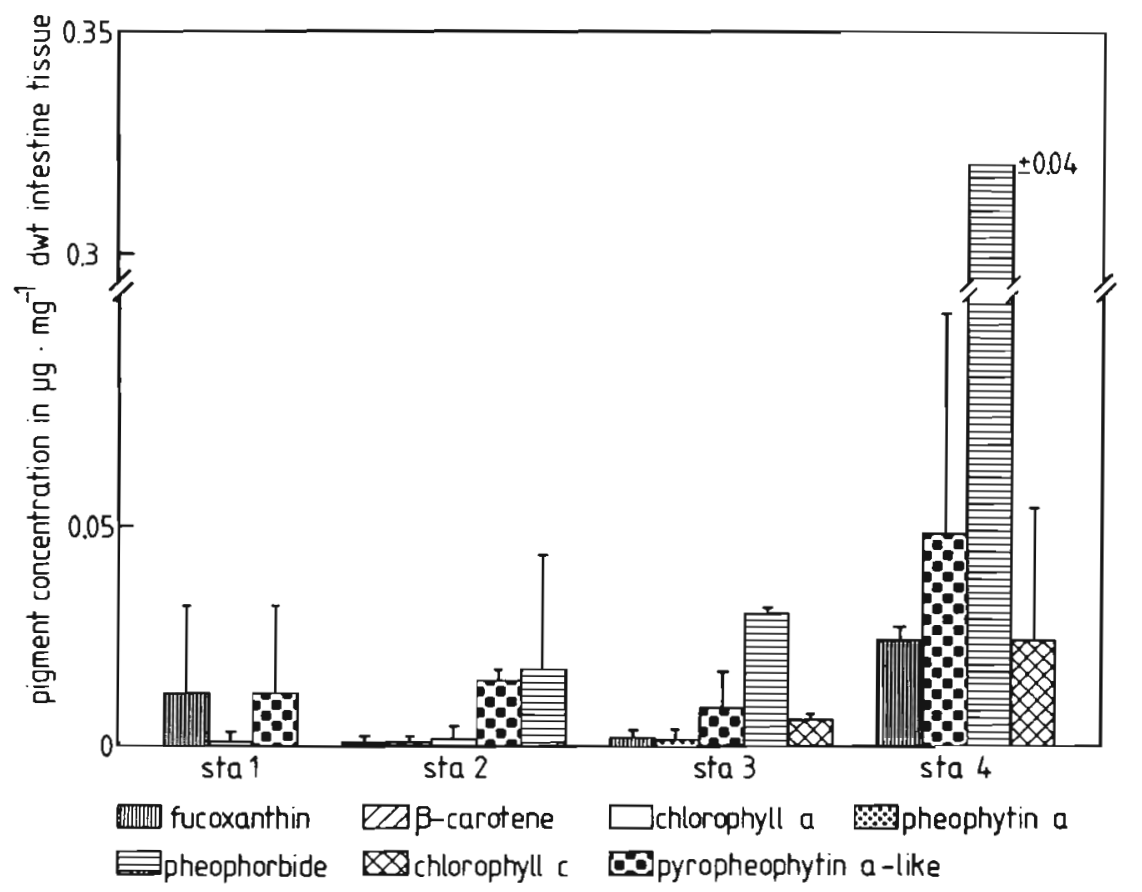

Fig. 2. Saduria entomon. Pigment concentrations in intestinal tissue in specimens from 4 different stations in the Gulf of Gdańsk. Data in $\mu \mathrm{g} \mathrm{mg}^{-1}$ dry wt of intestinal tissue. Means for June, August and September 1991
$550 / 552$, the mass of echinenone, and another distinct mass peak at 578 , which could not be ascribed to any known carotenoid structure.

\section{Feeding experiments}

Algae offered to Saduria entomon in the feeding experiment were rejected. Thus no pigments were found in isopods from Group 6 that had been fed Enteromorpha.
In contrast, isopods that had lived on carnivore diets (Groups 2 to 5; Fig. 4) contained considerable amounts of the derivative pheophorbide a. In Fig. 4 the amounts found in individuals from differently fed groups are shown. All data are given in $\mu \mathrm{g}$ pheophorbide $\mathrm{mg}^{-1}$ dry wt of intestinal tissue. While specimens in the control group had very low concentrations, and those (Group 6) fed algae contained no pheophorbide at all, the highest amounts of this chlorophyll breakdown product were found in specimens that had lived on Saduria entomon.

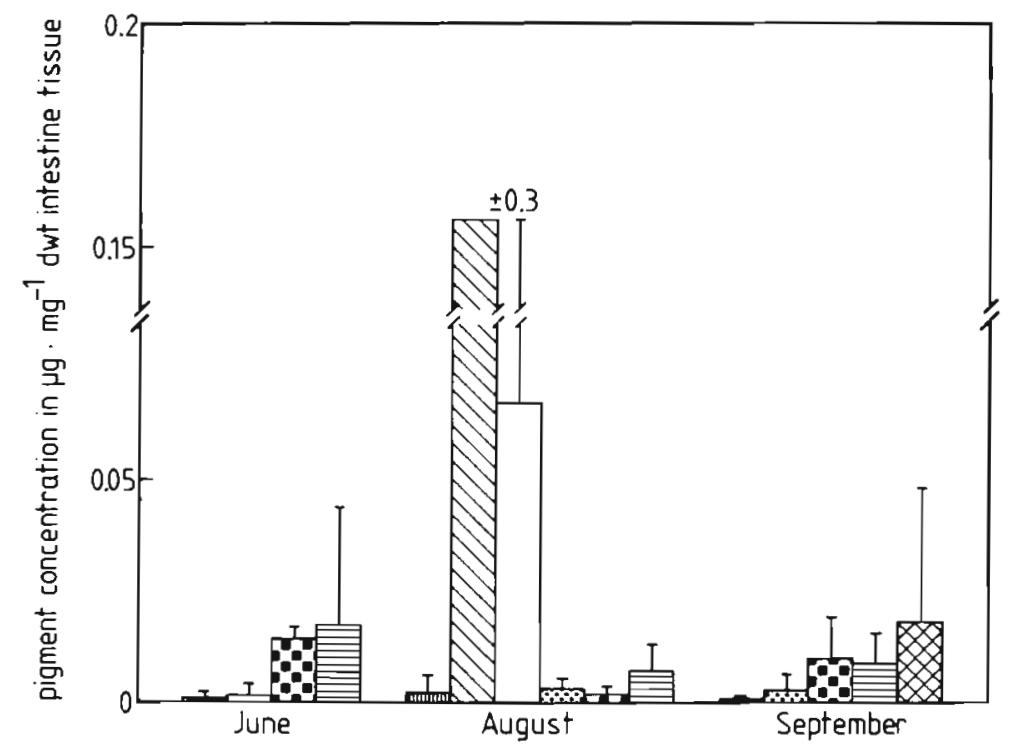

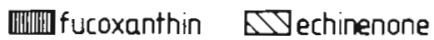

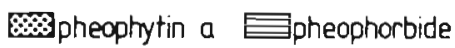

Jchlorophyll a 28 chlorophyll c

Opyropheophytin a-like
Fig. 3. Saduria entomon. Time series of pigment concentrations in intestinal tissue from Stn GN in the Gulf of Gdansk (32 $\mathrm{m}$ water depth). Data in $\mu \mathrm{g} \mathrm{mg}^{-1}$ dry wt of intestinal tissue. August 1990 
wg pheophorbide per mg tlssue dwt

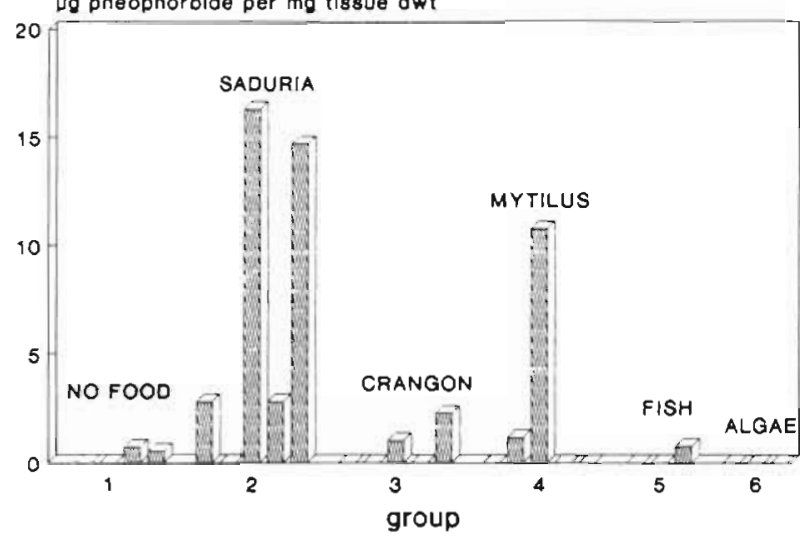

Fig. 4. Saduria entomon. Pheophorbide concentrations in the intestine of single individuals, after having been fed for 1 wk with: SADURIA, Saduria entomon; CRANGON, Crangon crangon; MYTILUS; Mytilus edulis; FISH, Zoarces viviparus

There was also one individual that had fed on the herbivorous filter feeder Mytilus edulis which contained high amounts of pheophorbide, while concentrations were low in Groups 3 and 5 that had fed on the carnivore Crangon crangon and the carnivorous fish Zoarces viviparus, respectively.

Isopods from Group 4 that had fed on Mytilus edulis additionally contained the diatom pigments fucoxanthin, diathoxanthin, diadinoxanthin and chlorophyll c. In Group 5, where the prey was fish, the dihydroxyxanthophyll lutein appeared in 2 out of 3 individuals.

Analysis of sediment samples from the experimental containers, before and after the experiment, yielded no measurable amounts of carotenoid or chlorophyllous pigments.

\section{DISCUSSION}

Analyses of pigments in the intestinal tract of an omnivorous cannibalistic species like Saduria entomon reveal the potential of these compounds to study the feeding preferences of individuals.

In June, pheophorbide a concentrations in specimens from Stns 1, 2 and 3 were low. The very small amounts of the diatom pigment fucoxanthin suggest that these isopods must have taken up plant material. Uptake of diatomaceous material from the sediment surface was also suggested by Polak \& Falkowski (1987) who found traces of free triglycerols of diatom origin in the tissue of Saduria entomon.

The pyropheophythin-like chlorophyll a derivative was detected in most of the in situ collected individuals. We have no definite evidence of the origin of this derivative, although King \& Repeta (1991) report formation of pyropheophorbide from pheophorbide occurring during grazing of algal material in the water column. These specimens may have ingested detritus, resulting from zooplankton activity, after its deposition on the sediment surface

The lack of pyropheophytin in the samples from the feeding experiment shows that this component is at least not produced by Saduria entomon itself, nor by the species offered as prey. It is not clear whether the formation of the pyropheophytin-like pigment may be connected to bacterial chlorophyll breakdown in faecal pellets. Baker \& Louda (1986) state that pheophorbide and pheophytin are the major chlorophyll derivatives generated during water column passage, and that loss of the carbomethoxy group, leading to the formation of pyroporphyrins, occurs in suboxic sediments. The pyropheophytin-like pigment, found in combination with chlorophyll $c$, fucoxanthin, and large amounts of pheophorbide in specimens from Stn 4, thus indicates uptake of pigments from the detritus pool in the sediment at this station. Due to the presence of algae the amount of detritus is presumably larger compared to the 3 other stations.

In samples collected in August only, large amounts of original chlorophyll $a$ in combination with echinenone reflected uptake of freshly sedimented material containing chlorophyll a, presumably of cyanophyte origin. Pheophorbide and the pyropheophytin a-like chloropigment were negligible in these samples, so uptake of detritus was limited and fresh material preferentially ingested. Cyanophyte mass blooms are typical for summer phytoplankton in the Baltic (Jochem 1989).

In the feeding experiment high amounts of the chlorophyll derivative pheophorbide were found in Saduria entomon individuals that fed cannibalistically. This shows that the prey contained large amounts of either original chlorophyll or pheopigment. Algae covering the carapax of prey individuals seem unlikely to be the source of this pheophorbide uptake, as no chlorophyll was found in the analysis of carapax samples.

Besides pheophorbide a the diatom xanthophylls (fucoxanthin, diadino- and diathoxanthin) plus chlorophyll $c$ were found in Saduria entomon that had been fed the filter feeder Mytilus edulis. This clearly showed pigment uptake from the mussel tissue, as again analyses of the sediment gave no positive result.

In contrast, uptake of plant pigments from predation on the carnivorous species Zoarces viviparus and Crangon crangon was not observed. Lutein was found in individuals predating the fish, and indeed lutein and a 3'epilutein-derivative are known constituents in the skin of teleost fish (Matsuno \& Hirao 1989). 
Gut pigment content proved a valuable indicator for varying food supply. Uptake of freshly sedimented phytoplankton resulted in distinct levels of undegraded chlorophyll plus various planktonic carotenoids in the intestinal tract of Saduria entomon. When feeding on herbivorous animals like Mytilus edulis the chlorophyll in the predator was completely converted into pheophorbide, but the planktonic carotenoids were still detectable. No chloropigments were found in the intestine after predation on carnivorous species (Crangon crangon, Zoarces viviparus). Instead carotenoids originating from the tissue of the prey (lutein, canthaxanthin) were found. Consumption of detritus from the sediment surface is reflected by the presence of pyroporphyrins and pheophorbide in $S$. entomon. Both classes of pigments are promising markers. While carotenoids have higher source specificity, chlorophylls are better markers when metabolic pathways are studied.

The question whether plant pigments are assimilated by Saduria entomon was not extensively treated in this study. We found $\beta$-carotene and also echinenone in the carapax and gonads, and we believe that, like in most marine and terrigenous species, these substances are either directly used or derivatized for antioxidant protection in the isopod's tissue. Marsh et al. (1990) found assimilation of carotenoids from dietary food into the oocytes of the polychaete Capitella sp., and concluded that these substances could be micronutrients, similar to vitamins, that are essential cofactors in biochemical reactions. A conceivable function of assimilated carotenoids is that of antioxidant protection of lipids and other macromolecules in animal tissue (Burton \& Ingold 1984). This seems to apply to our study of $S$. entomon which is an animal mostly adjusted to a carnivorous diet, but seems to depend on a supply of algal or detritic material from time to time.

Acknowledgements. We thank Dr W. Tuszynski, Department of Physics, University of Oldenburg, FB 8 for carrying out the mass-spectrometric analyses. This work was supported by DFG fund Ab 64/1-1 to D. Abele-Oeschger. We thank P. wenke for excellent technical assistance, and $H$ Raudszus for drawing the figures.

\section{LITERATURE CITED}

Abele, D. (1988). Carotinoide als biogene Marker für benthische Makroalgen im Sediment der Kieler Bucht. Ber. Inst. Meereskunde Univ. Kiel 183: 1-116

Abele-Oeschger, D. (1991). Potential of some carotenoids in two recent sediments of Kiel Bight as biogenic indicators of phytodetritus. Mar. Ecol. Prog. Ser. 70: 83-92

Abele-Oeschger, D., Theede, H. (1991). Digestion of algal pigments by the common periwinkle Littorina littorea $\mathrm{L}$. (Gastropoda). J. exp. mar. Biol. Ecol. 147: 177-184.
Baker, E. W., Louda, J. W. (1986). Porphyrins in the geological record. In: Johns, R. B. (ed.) Biological markers in the sedimentary record. Elsevier. Amsterdam, p. 125-225

Bianchi, T S., Findlay, S. (1990). Plant pigments as tracers of emergent and submergent macrophytes from the Hudson River. Can. J. Fish. Aquat. Sci. 47: 492-494

Bianchi, T S., Dawson, R., Sawangwong, P. (1988). The effects of macrobenthic deposit-feeding on the degradation of chloropigments in sandy sediments. J. exp. mar. Biol. Ecol. 122: 243-255

Burton, G. W., Ingold, K. U. (1984). $\beta$-Carotene: an unusual type of lipid antioxidant. Science 224: 569-573

Dawson, R., Kalbfleisch, J., Liebezeit, G., Llewellyn, C. A., Mantoura, R. F. C., Moreau, F., Poulet, S. A. (1985). HPLC analyses of dissolved free amino acids, pigments and vitamins in plankton and particles. Océanis 11: 521-530

Downs, J. N., Lorenzen, C. J. (1985). Carbon: pheopigment ratios of zooplankton fecal pellets as an index of herbívorous feeding. Limnol. Oceanogr. 30: 1024-1036

Gieskes, W. W., Kraay, G. W. (1983). Dominance of Cryprophyceae during the phytoplankton spring bloom in the central North Sea detected by HPLC analysis of pigments. Mar. Biol. 75: 179-185

Gieskes, W. W., Kraay, G. W. (1984). Phytoplankton, its pigments and primary production at a central North Sea station in May, July and September 1981. Neth. J. Sea Res 18: $51-70$

Haahtela, I. (1990). What do Baltic studies tell us about the isopod Saduria entomon (L.)? Annls. Zool. fenn. 27: $269-278$

Hagerman, L., Szaniawska, A. (1988). Respiration, ventilation and circulation under hypoxia in the glacial relict Saduria (Mesidotea) entomon. Mar. Ecol. Prog. Ser. 47: 55-63

Hagerman, L., Szaniawska, A. (1990). Anaerobic metabolic strategy of the glacial relict Saduria (Mesidotea) entomon. Mar. Ecol. Prog. Ser. 59:91-96

Juhler, R. K., Cox, R. P. (1990). High performance liquid chromatographic determination of chloroplast pigments with optimized separation of lutein and zeaxanthin. J. Chromatogr. 508: 232-235

King, L. L., Repeta, D. J. (1991). Novel pyropheophorbide steryl esters in Black Sea sediments. Geochim. Cosmochim. Acta 55: 2067-2074

Kivivuori, L., Lagerspetz K. Y H. (1990). Thermal resistance and behaviour of the isopod Saduria entomon (L.). Annls. Zool fenn. 27: 287-290

Lehmann, P. W. (1981). Comparison of chlorophyll-a and carotenoid pigments as predictors of phytoplankton biomass. Mar. Biol. 65: 237-244

Leonardsson, K. (1990). Cannibalism as a population regulating mechanism in the brackish-water isopod Saduria entomon (L.). Annls. Zool. fenn. 27: 285

Liaaen-Jensen. S. (1990). Marine carotenoids - selected topics. New. J. Chem. 14:747-759

Liaaen-Jensen, S. (1991). Marine carotenoids: recent progress. Pure appl. Chem. 63 (1): 1-12

Mantoura, R. F. C., Llewellyn, C. A. (1983). The rapid determination of algal chlorophyll and carotenoid pigments and their break down products in natural waters by HPLC. Anal. Chim. Acta 151. 297-314

Marsh, A. G., Gremare, A., Dawson, R., Tenore, K. R. (1990). Translocation of algal pigments to oocytes in Capitella sp. I (Annelida: Polychaeta). Mar. Ecol. Prog. Ser. 67: $301-304$

Matsuno, T. Hirao, S. (1989). Marine animal carotenoids in. fish. In: Marine biogenic lipids, fats and oils. Ackmann, R. G. (ed.) CRC Press Inc., Boca Raton, p. 323-345 
Polak, L., Falkowski, L. (1987). Content and composition of lipids in Mesidotea entomon L. (Crustacea, Isopoda). Pol. Arch. Hydrobiol. 34: 239-244

Riaux-Gobin, C., Llewellyn, C. A., Klein, B. (1987). Microphyto-benthos from two subtidal sediments from North Brittany. II. Variations of pigment compositions and concentrations determined by HPLC and conventional techniques. Mar. Ecol. Prog. Ser. 40: 275-283

Sandberg, E., Bonsdorff, E. (1990). On the structuring role of $S$. entomon (L.) on shallow water zoobenthos. Annls zool. fenn. 27: $279-284$

This article was submitted to the editor
Theede, H. (1974). Die Tierwelt der Ostsee. I. Ökologie. In: Magaard, L., Rheinheimer, G. (eds.) Meereskunde der Ostsee. Springer Verlag, Berlin, p. 178-188

Wright, S. W., Jeffrey, S. W. (1987). Fucoxanthin pigment markers of marine phytoplankton analysed by HPLC and HPTLC. Mar. Ecol. Prog. Ser. 38: 259-266

Züllig, H. (1982). Untersuchungen über die Stratigraphie von Carotinoiden im geschichteten Sediment von 10 Schweizer Seen zur Erkundung früherer PhytoplanktonEntfaltungen. Schweiz. Zeitg. f. Hydrol. 44: 1-98

Manuscript first received: August 16, 1991

Revised version accepted: February 25, 1992 